\title{
Study regarding the game parameters of the national men's basketball league and of the national team at Eurobasket 2017
}

\author{
Dan IONESCU1 ${ }^{1}$, Rareş Cosmin PRIŞCĂ²
}

\begin{abstract}
The problem of the native player in the Romanian basketball generated a lot of pros and cons. To take a stand in this issue, in order to protect the Romanian player, starting with the 2015-2016 season, the Romanian Basketball Federation introduced the rule of presence of the local player on the court at each official match. Thus, at Romanian Cup matches, at least two Romanian players must be permanently on the court, and at the National League matches there must be at least one Romanian player at all times.

Starting from the hypothesis that the value of the national team increases through the first echelon, this study aims to analyze and compare the game parameters registered in the National Men's Basketball League (LNBM) and those made by the national team of Romania at Eurobasket 2017.
\end{abstract}

Key words: Basketball, Game Parameters, NMBL (National Men's Basketball League), Eurobasket 2017

\section{Rezumat}

Problema jucătorului autohton în baschetul românesc a generat o multitudine de argumente pro și contra. Ca o luare de poziție în această problemă, pentru a proteja jucătorul român, începând din sezonul competițional 2015-2016, Federația Română Baschet a introdus regula jucătorului autohton obligatoriu pe teren la fiecare meci oficial. Astfel la meciurile din Cupa României trebuie să se afle în permanență pe teren minimum 2 jucători români, iar la meciurile din Liga Națională există obligativitatea utilizării în permanență a cel puțin 1 jucător român.

Pornind de la ipoteza că valoarea echipei naționale crește prin intermediul primului eșalon, acest studiu și-a propus analizarea și compararea parametrilor de joc înregistrați în Liga Națională de Baschet Masculin (LNBM) și cei realizați de echipa națională a României la Eurobasket 2017.

Cuvinte cheie: Baschet, Parametrii de joc, LNBM (Liga Națională de Baschet Masculin), Eurobasket 2017

\footnotetext{
${ }^{1}$ Lecturer, "Politehnica" University Timișoara, Romania, e-mail: dan.ionescu@upt.ro

2 Prof., Ațel Gymnasial School, Sibiu, Romania
} 


\section{Introduction}

The rule of the native basketball player has generated a multitude of for and against arguments. It is true that the introduction of foreign players has led to the sport becoming more spectacular, which in turn has brought in more spectators. However, it is also true that, due to budget restraints, Romanian teams have only managed to enlist less valuable players or players towards the end of their careers. Cases in which the situation was different are few and far in between. In order to protect the Romanian player, the Romanian Basketball Federation has introduced the rule of the native player, compelling all teams to field at least one Romanian player during Championship games, and at least two during Cup games. Due to the implementation of this rule, the coaches and managers' attention has naturally turned to Romanian players, which has resulted in changes in the way teams are put together, but also in their game plan.

\section{The study's hypotheses and objectives}

Starting from the premise that the value of the National Team increases through its first league, we propose to analyse and compare the game parameters registered by the Men's National Basketball League to those registered by the Romanian National Team at the 2017 Eurobasket. The objectives of this paper has been to find out:

-To what extent the efficiency of the basketball shots differs from a national to an international level;

-To what extent the other game parameters (with the exception of basketball shots) differ from national to international level:

-The individual performance and the place gained by the Romanian players selected to the National Team, in the National League's rankings.

\section{The used method and the study subjects}

In order to achieve our research purpose, we employed the following methods [1]:

-The observation

It presupposes observing the phenomenon without the researcher's intervention on the organization or the progress of the object under scrutiny [2], for instance by recording the games.
The statistical indicators calculated were:

\section{-The arithmetic mean $(\bar{X})$}

Very commonly used, this parameter is considered to be a typical value in appreciating the central trend of the studied phenomenon. When calculating the arithmetic mean, one must take into account that it can be strongly influenced by certain extreme values, which may lead to misleading conclusions. To calculate the arithmetic mean, the following formula should be used:

$$
\bar{X}=\frac{\Sigma \chi}{n}
$$

where: $\bar{X}=$ the arithmetic mean

$\Sigma \chi=$ the sum of individual values

$\mathrm{n}=$ the total number of cases

\section{-The median ( $m d n$ )}

It divides the sample in two equal parts. The median and the arithmetic mean show central tendencies and should be seen in correlation. When the sample is homogeneous [3], the two values cluster together, until sometimes they overlap.

-The standard deviation $(\sigma)$

It is one of the most significant parameters of variation. It is calculated with the formula:

$$
\sigma=\sqrt{\frac{\sum(x 1-x)}{n-1}}
$$

where: $\sigma=$ the standard deviation

$\Sigma=$ the summation of results

$\mathrm{x} 1-\mathrm{x}=$ the deviation of individual values

from the means

$\mathrm{n}=$ the total number of cases

The distribution is called normal if a standard deviation from left and right encompasses over $68 \%$ of cases. It is important to remember that the smaller the dispersion, the more representative the central value is.

-The coefficient of variation $\left(C_{\nu}\right)$

It represents the ratio of standard deviation to arithmetic mean. This parameter is expressed as a percentage and the calculation formula is the following:

$$
\mathrm{Cv}=\frac{S x \cdot 100}{x}
$$


The coefficient of variation is often used in order to find the degree of homogeneity for a collective. Thus, the coefficient of variation may have the following values:

$0-10 \% \rightarrow$ small dispersion $\rightarrow$ great homogeneity

$10-20 \% \rightarrow$ average dispersion $\rightarrow$ average homogeneity

over $20 \% \rightarrow$ great dispersion $\rightarrow$ lack of homogeneity

\section{-Charts}

They are used in order to facilitate the understanding of the material presented, to illustrate the analyzed facts more clearly [4].

The subjects of the paper were all members of the 11 teams participating in the Men's National Basketball League during the 2016-2017 competitive season. The games in the Men's National Basketball League were organized as follows:

Phase 1. Round-robins, all-play-all games, weekly stages;

Phase 2. In two groups 1-6 and 7-11, round-robin, all-play-all games, weekly stages;

Phase 3. Play off places 1-8, elimination games.

After all the matches, the final standings were as follows [5]: 1. U - Banca Transilvania Cluj Napoca; 2. Steaua CSM Eximbank București; 3. CSM CSU Oradea; 4. BC CSU Sibiu; 5. BC SCM Timișoara; 6. BCMU Pitești; 7. BC Mureș Tg. Mureș; 8. SCMU Craiova; 9. CS Phoenix Galați; 10. CS Dinamo București; 11. BC Olimpic Baia Mare (the team pulled out of the Championship after Phase 1).

\section{The results obtained}

The game parameters registered in the League games, as well as those of the Romanian National Team at the 2017 Eurobasket, underwent statistical processing based on the following indices:

-Grouping indices - the mean and the median;

-Dispersion indices - the standard deviation and the coefficient of variation;

The data obtained were introduced in tables and histograms:
Legend:

\begin{tabular}{|l|l|}
\hline 2P FG - 2-point field goals & R - Rebounds \\
\hline 3P FG - 3-point field goals & OFF - offensive \\
\hline A - points shot & DEF - defensive \\
\hline M - points scored & TOT - total \\
\hline FG - field goals & AS - assists \\
\hline FT - free throws & TO - turnovers \\
\hline MJ - matches played & ST - steals \\
\hline EFF - efficiency & BS - blocked shots \\
\hline & PF - personal faults \\
\hline & PTS - points scored \\
\hline
\end{tabular}

As far as the basketball shots in the Men's National Basketball League are concerned (Table 1), for all the analyzed parameters, the grouping indices, the mean and the median, have close or central positions in the distribution. This shows that the means are representative.

The index of dispersion, the standard deviation, is quite low, with values between 1.09 and 3.00, in all types of shots. This describes the position of individual values in relation to the mean, grouping the sample close to it. As far the percentage of all types of shots is concerned, the sample's performance has dispersions from the mean between the values of $4.10-8.09$.

The coefficient of variation reflects the differences between the teams, the degree of homogeneity ranging between high and medium (in the case of successful 3-point field goals and free throws).

Table 1. The parameters of shots in the Men's National Basketball League, 2016/2017 season

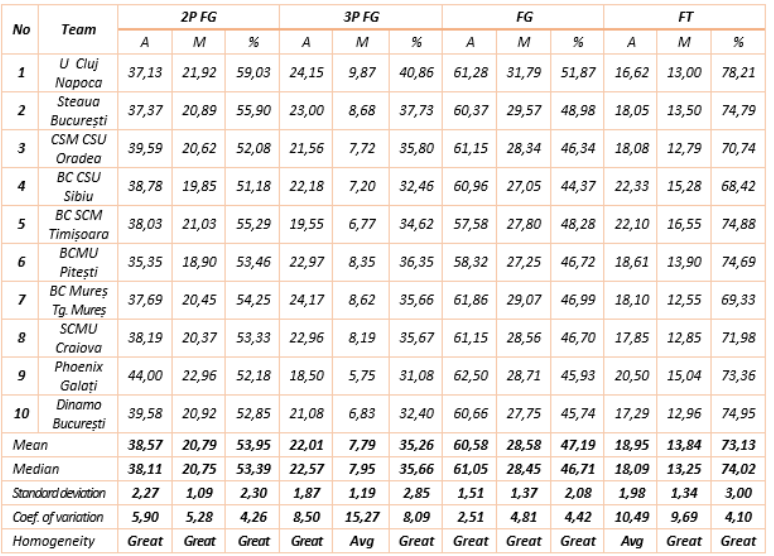


Table 2. The parameters of shots in the Romanian team at the 2017 Eurobasket

\begin{tabular}{|c|c|c|c|c|c|c|c|c|c|c|c|c|c|}
\hline \multirow{2}{*}{ No } & \multirow{2}{*}{$\begin{array}{c}\text { Romania at } \\
\text { EuroBasket } \\
2017 \\
\text { Jocul }\end{array}$} & \multicolumn{3}{|c|}{$2 P F G$} & \multicolumn{3}{|c|}{$3 P F G$} & \multicolumn{3}{|c|}{$F G$} & \multicolumn{3}{|c|}{$F T$} \\
\hline & & $A$ & $M$ & $\%$ & $A$ & $M$ & $\%$ & $A$ & $M$ & $\%$ & $A$ & $M$ & $\%$ \\
\hline 1 & $\begin{array}{l}\text { Romania- } \\
\text { Crech Repubici }\end{array}$ & 36 & 13 & 36,1 & 21 & 9 & 42,9 & 57 & 22 & 38,6 & 19 & 15 & 78,9 \\
\hline 2 & $\begin{array}{l}\text { Croatio- } \\
\text { România }\end{array}$ & 39 & 21 & 53,8 & 27 & 5 & 18,5 & 66 & 26 & 39,4 & 2 & 1 & 50 \\
\hline 3 & $\begin{array}{l}\text { Spain- } \\
\text { Romania }\end{array}$ & 40 & 13 & 32,5 & 24 & 7 & 29,2 & 64 & 20 & 31,3 & 8 & 3 & 37,5 \\
\hline 4 & $\begin{array}{l}\text { Romania - } \\
\text { Hungory }\end{array}$ & 42 & 21 & 50 & 14 & 4 & 28,6 & 56 & 25 & 44,6 & 27 & 17 & 63 \\
\hline 5 & $\begin{array}{l}\text { Montenegro } \\
\text { - Romania }\end{array}$ & 43 & 20 & 46,5 & 23 & 7 & 30,4 & 66 & 27 & 40,9 & 12 & 8 & 66,7 \\
\hline Med & & 40 & 17,60 & 43,78 & 21,80 & 6,40 & 29,92 & 61,80 & 24,00 & 38,96 & 13,60 & 8,80 & 59,22 \\
\hline & & 40,00 & 20,00 & 46,50 & 23,00 & 7,00 & 29,20 & 64,00 & 25,00 & 39,40 & 12,00 & 00 & 63,00 \\
\hline & dord deviotion & 2,74 & 4,22 & 12 & 4,87 & 1,94 & 8,68 & 4,92 & 2,92 & 4,86 & 9,71 & 7,09 & 15,92 \\
\hline & of variation & 6,85 & 23,97 & 20,83 & 22,33 & 30,46 & 29,01 & 7,96 & 12,15 & 12,48 & 71,40 & 80,51 & 26,89 \\
\hline & nogeneity & Great & Lack & Lock & Lock & Lock & Lack & Great & Avg & Avg & Lack & Lack & $c k$ \\
\hline
\end{tabular}

Where the parameters of basketball shots achieved by the Romanian National Team at the 2017 Eurobasket [6] are concerned (Table 2), the statistical calculation shows us that the grouping indices also cluster together. The values of the dispersion indices, the standard deviation, and especially the coefficient of variation, emphasize a negative aspect, namely the fluctuations from one game to another of the team during the European Championship.

Chart 1. The mean of basketball shots parameters

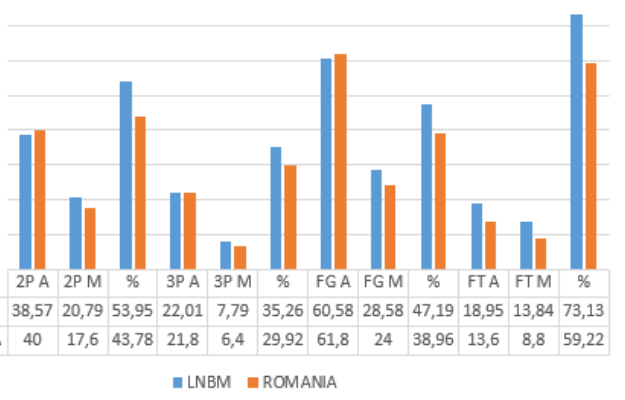

After analyzing basketball shots (Chart 1), we can conclude that the Men's National Basketball League's mean is below that of the National Team when it comes to attempted field-goals, 60.58 to 61.80. Nevertheless, the percentage of these shots was 47.19 to 38.96 in favor of the League's mean. The situation of the free throws is completely different, however. The League's mean is far superior to that of the National Team when it comes to the number of attempted free throws (18.95 to $13.60)$ as well as in the case of the number of successful free throws (13.84 to 8.80). The number of successful throws was also reflected in the percentage of this type of shot, 73.13 to 59.11 in favor of the League.
The calculated mathematical indices when it comes to the other game parameters in the Men's National Basketball League (Table 3), as well as those of the National Team (Table 4) follow the same coordinates as the parameters mentioned above, concerning basketball shots. Generally, in both cases, the grouping indices are close which means that the means are representative, whereas the parameters of dispersion are high, reflecting the differences between the League teams, but also the National Team's fluctuating evolution during the European Championship.

Table 3. Game parameters in the Men's National Basketball League - the 2016/2017 season

\begin{tabular}{|c|c|c|c|c|c|c|c|c|c|c|}
\hline \multirow{2}{*}{ No } & \multirow{2}{*}{ Team } & \multicolumn{3}{|c|}{ Rebounds } & \multirow{2}{*}{ AS } & \multirow{2}{*}{ то } & \multirow{2}{*}{ st } & \multirow{2}{*}{ BS } & \multirow{2}{*}{ PF } & \multirow{2}{*}{ PTS } \\
\hline & & OFF & DEF & TOT & & & & & & \\
\hline 1 & U- BT Cluj Napoco & 9,33 & 23,92 & 33,25 & 20,13 & 13,26 & 6,95 & 1,97 & 20,72 & 86,46 \\
\hline 2 & Steaua Bucuresti $i$ & 11,34 & 23,39 & 34,73 & 17,05 & 13,76 & 6,11 & 2,55 & 22,08 & 81,34 \\
\hline 3 & CSM CSU Oradea & 10,00 & 23,51 & 33,51 & 19,10 & 13,05 & 7,26 & 2,15 & 19,64 & 77,18 \\
\hline 4 & BC CSU Sibiu & 11,38 & 22,93 & 34,31 & 15,85 & 12,65 & 7,15 & 2,15 & 20,80 & 76,58 \\
\hline 5 & BC SCM Timissoaro & 9,10 & 22,61 & 31,71 & 17,42 & 15,87 & 7,84 & 1,90 & 22,00 & 78,94 \\
\hline 6 & BCMU Pitesti & 9,35 & 24,13 & 33,48 & 17,48 & 15,90 & 5,87 & 2,65 & 20,68 & 76,77 \\
\hline 7 & $B C$ Mures Tg. Mures & 10,86 & 23,86 & 34,72 & 17,28 & 14,24 & 7,14 & 3,31 & 21,72 & 79,31 \\
\hline 8 & SCMU Croiova & 9,41 & 25,11 & 34,52 & 17,30 & 13,48 & 5,48 & 2,07 & 21,78 & 78,15 \\
\hline 9 & CS Phoenix Galatiti & 9,96 & 20,58 & 30,54 & 18,92 & 15,08 & 9,04 & 1,63 & 22,58 & 78,21 \\
\hline 10 & CS Dinomo Bucuresti & 9,08 & 23,04 & 32,12 & 16,58 & 15,13 & 7,08 & 1,83 & 20,46 & 75,29 \\
\hline Mea & & 9,98 & 23,30 & 33,28 & 17,71 & 14,24 & 6,99 & 2,22 & 21,24 & 78,82 \\
\hline & & 9,68 & 23,45 & 33,49 & 17,36 & 14,00 & 7,11 & 2,11 & 21,26 & 78,18 \\
\hline & eviotion & 0,90 & 1,19 & 1,42 & 1,28 & 1,18 & 1,02 & 0,49 & 0,91 & 3,17 \\
\hline & iation & 9,03 & 5,12 & 4,27 & 7,27 & 8,32 & 14,59 & 22,16 & 4,31 & 4,02 \\
\hline & & Great & Great & Great & Great & Great & Avg & Lack & Great & Great \\
\hline
\end{tabular}

Table 4. Game parameters of the Romanian National Team at the 2017 Eurobasket

\begin{tabular}{|c|c|c|c|c|c|c|c|c|c|c|}
\hline \multirow{2}{*}{ No } & \multirow{2}{*}{$\begin{array}{l}\text { Romania at Eurobasket } 2017 \\
\text { Game }\end{array}$} & \multicolumn{3}{|c|}{ Rebounds } & \multirow{2}{*}{ AS } & \multirow{2}{*}{ то } & \multirow{2}{*}{ st } & \multirow{2}{*}{ BS } & \multirow{2}{*}{ PF } & \multirow{2}{*}{ PTS } \\
\hline & & OFF & DEF & TOT & & & & & & \\
\hline 1 & Romania - Czech Republic & 11 & 30 & 41 & 19 & 21 & 3 & 5 & 21 & 68 \\
\hline 2 & Croatia-Romania & 7 & 21 & 28 & 17 & 9 & 7 & 4 & 25 & 58 \\
\hline 3 & Spoin-Romania & 12 & 17 & 29 & 15 & 15 & 4 & 0 & 24 & 50 \\
\hline 4 & Romonia - Hungary & 5 & 23 & 28 & 16 & 11 & 8 & 0 & 24 & 71 \\
\hline 5 & Montenegro - Romonia & 9 & 24 & 33 & 25 & 11 & 9 & 1 & 17 & 69 \\
\hline \multicolumn{2}{|c|}{ Mean } & 8.80 & 23,00 & 31,80 & 18,40 & 13,40 & 6,20 & 2,00 & 22,20 & 63,20 \\
\hline \multicolumn{2}{|c|}{ Median } & 9,00 & 23,00 & 29,00 & 17,00 & 11,00 & 7,00 & 1,00 & 24,00 & 68,00 \\
\hline \multicolumn{2}{|c|}{ Standard deviotion } & 2,86 & 4,74 & 5,54 & 3,97 & 4,77 & 2,59 & 2,35 & 3,27 & 8,93 \\
\hline \multirow{2}{*}{\multicolumn{2}{|c|}{$\begin{array}{l}\text { Coef of variation } \\
\text { Hom ogeneity }\end{array}$}} & 32,54 & 20,62 & 17,42 & 21,60 & 35,63 & 41,75 & 117,26 & 14,73 & 14,13 \\
\hline & & Lack & Lack & Avg & Lack & Lack & Lack & Lack & Avg & Avg \\
\hline
\end{tabular}

Analyzing the game parameters' mean (Chart 2) has evinced the following characteristics:

-The average number of board rebounds is higher in the League: 33.28 to 31.80 . These numbers result from the sum of offensive rebounds (9.98 to 8.8) and defensive rebounds (23.3 to 23). Both are in favour of the League.

-Insofar as the number of assists is concerned, statistics show that the mean of the National Team is higher than that of the League: 18.4 to 17.71 .

-Another parameter whose mean favours the National Team is the number of turnovers, 13.4 to 14.28. This may be due to the poor performance of the teams at the bottom of the League, which had a 
significant contribution in establishing the final value of this parameter.

-Rebounds through steals have a higher mean in the League games, 6.99 to 6.2 .

-Blocks also have a higher frequency, 2.22 to 2 , in the League.

-Where fouls are concerned, the statistics show that the number is greatest in the National Team: 22.2 to 21.24.

-The total number of points scored result from those discussed above. The mean was again the favour of the League games, 78.82 to 63.2.

Chart 2. Game parameter mean

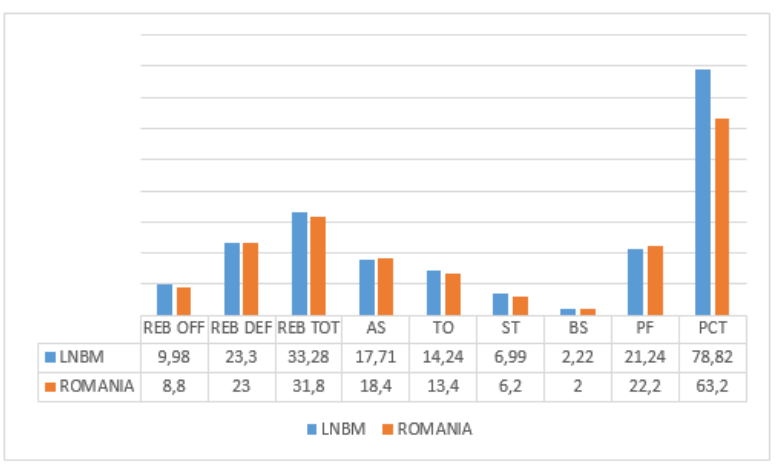

The results of the National Team can be partly explained by the "value" of its members. In the 2016/2017 season, the 10 players of the National Team, who played in the national championship, achieved the following results (Table 5). In brackets, we show the place in a League classification for each parameter.

Table 5. The results of the 10 national basketball team players selected from the national championship.

\begin{tabular}{|c|c|c|c|c|c|c|}
\hline \multirow{2}{*}{ Player } & \multirow{2}{*}{ Team } & \multicolumn{5}{|c|}{ Parometers } \\
\hline & & $G P$ & EFF & PCT & REB & AS \\
\hline MANDACHE Andrei & CSM CSU Oradea & 36 & $9,4(47)$ & $9,4(42)$ & $2,2(61)$ & $2,1(35)$ \\
\hline PETRIȘOR Cŏtŏllin & CSM CSU Oradea & 34 & $2,0(82)$ & $1,4(93)$ & $0,7(92)$ & $1,3(50)$ \\
\hline PALICIUC Radu & BC CSU Sibiu & 37 & $4,7(66)$ & $4,9(64)$ & $1,7(69)$ & $0,8(66)$ \\
\hline MOLDOVEANU VIad & U-BT Cluj Napoca & 34 & $17,6(7)$ & $15,5(7)$ & $5,7(12)$ & $2,5(32)$ \\
\hline NICOLESCU Bogdan & CSM CSU Oradea & 33 & $1,8(85)$ & $1,6(89)$ & $1,0(79)$ & $0,3(91)$ \\
\hline CALOTĂ-POPA Octovian & BC SCM Timisoara & 30 & $8,9(51)$ & $10,8(35)$ & $2,3(60)$ & $3,0(23)$ \\
\hline NICOARÁ TItUS & CSM CSU Oradea & 30 & $9,6(44)$ & $7,8(51)$ & $4,9(23)$ & $0,9(59)$ \\
\hline TOROK Rolland & U-BT Cluj Napoca & 39 & $8,5(55)$ & $7,0(57)$ & $3,9(37)$ & $0,5(80)$ \\
\hline BACIU Cŏtălin & Steauo București & 30 & $8,5(56)$ & $7,0(56)$ & $3,6(41)$ & $0,5(79)$ \\
\hline KUTI Nandor & U-BT Cluj Napoca & 25 & $3,0(75)$ & $3,1(72)$ & $1,2(75)$ & $0,9(62)$ \\
\hline
\end{tabular}

The table yields the following observations:

-Moldoveanu Vlad, placed $7^{\text {th }}$ on the League charts, is the most efficient Romanian player.

-In the most points scored chart, only three players qualified in the Top 50, Moldoveanu Vlad $7^{\text {th }}$ place,
Nicoară Titus $44^{\text {th }}$ place, and Mandache Andrei $47^{\text {th }}$ place.

-Where board rebounds are concerned, there is no Romanian player in the Top 10. Moldovan Vlad comes $12^{\text {th }}$. In the Top 50 , we also have Nicoară Titus, 23 ${ }^{\text {rd }}$, Torok Rolland, $37^{\text {th }}$, and Baciu Cătălin, $41^{\text {st. }}$.

-Calotă-Popa Octavian, the best Romanian player in

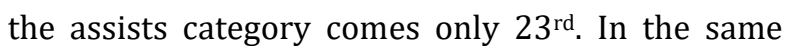
category, we find Moldoveanu Vlad in 32nd place, and Mandache Andrei in $35^{\text {th }}$ place.

\section{Conclusions}

Following our study, we could draw these conclusions:

-In most cases, the game parameter means in the Men's National Basketball League are superior to those achieved by the National Team. Therefore, we can affirm that the value National Team does not increase by way of the national Championship (our hypothesis is disproved).

-The catchment area for selecting players in the National Team is very small, which leads to including players whose performances in the national Championship are mediocre.

-The selected players came only from the first 5 teams in the League. Enforcing the rule of the native player has led to consecrated players migrating to pretentious teams, prospective players to relatively stable teams from a financial point of view, and young players to teams whose finances do not allow them to attract the big names of Romanian basketball.

-Introducing the rule of the native player is not enough to increase the performance of the National Team. Personally, I believe that maintaining this rule alongside educating and training coaches at junior level, introducing a stimulating system for the children and juniors where they can play many matches, and then promoting them in the first League could represent a solution.

\section{Discussion}

The phrase "National League" is artificial. It can be replaced at any moment with another, such as First League, Super League, A Division. You can't use the word "national" as long as, at least statistically, half of each participating team consists of foreign members (players and technical staff). 


\section{References}

1. Bachner L. (1998). Obiectivizarea jocului de baschet, Editura Mirton, Timișoara;

2. Hanțiu I. (2013). Educație fizică și sport. Teorie și metodică (Note de curs) Oradea;

3. Popa Gh. (1999). Metodologia cercetării științifice în domeniul educației fizice și sportului, Editura Orizonturi Universitare, Timișoara

4. Ciosici D. (2009). Metodologia cercetării științifice, Editura Politehnica, Timișoara

5. http://www.frbaschet.ro/campionat-masculin/liga-nationalade-baschet/statistici-echipe/ Retrieved August 25, 2017

6.http://www.fiba.basketball/ro/eurobasket/2017

Retrieved September 20, 2017 